\title{
Radiogenic and stable isotope studies of hot-spring deposits in Yellowstone National Park and their genetic implications
}

\author{
W. P. LeEMAN ${ }^{*}$, B. R. Doe and Joseph Whelan \\ U.S. Geological Survey, Box 25046, Denver Federal Center, Denver, Colorado 80225 U.S.A.
}

(Received January 29, 1977)

\begin{abstract}
Samples of travertine and siliceous sinter from hot-spring deposits in Yellowstone National Park of northwestern Wyoming have been analyzed for light stable (carbon and oxygen) and radiogenic (lead and strontium) isotopes. The Hillside Springs travertine contains significantly lighter $\delta^{13} \mathrm{C}$ than the previously studied Mammoth travertine. Although this relation could indicate a component of magmatic carbon, more likely it reflects a higher temperature of precipitation for Hillside Spring travertine. Our data on Mammoth travertine shows it to have been precipitated substantially below the orifice temperature. The oxygen isotope data on the newly analyzed deposits confirm the previous studies that found the hot-spring waters to be dominated by meteoric water. The lead isotope data show that there is a sedimentary component of lead in all the hot-spring deposits analyzed, including those inside the caldera limits. Either long lateral migration of waters are involved in the recharge of the springs or there must be sediments buried at some unknown depth beneath the volcanic rocks inside the caldera because no sediments are known at the surface. The high rainfall inside the limits of the caldera would favor sediments buried at depth.
\end{abstract}

\section{INTRODUCTION}

Geothermal power has gained increasing importance in recent years (WHITE, 1969, 1971; MAHON, 1971; ElLIS, 1971). Information about sources of water and recharge areas is necessary in understanding the behavior of hydrothermal systems. In this paper we present $\mathrm{Pb}$ and $\mathrm{Sr}$ isotopic analyses of siliceous and carbonate hotspring deposits in Yellowstone National Park, U.S.A., and similar analyses of sedimentary and volcanic rocks in that area in an attempt to trace the origin of thermal waters there. In particular, an important question is whether these waters contain a magmatic component. Such a magmatic component, if any exists, should be easier to detect in an area such as Yellowstone Park, where present-day hydrothermal activity is closely associated with voluminous rhyolitic volcanism. For this purpose, isotopic tracers (e.g., $\mathrm{Pb}$ and $\mathrm{Sr}$ ) are more sensitive than chemical properties as indicators of the kinds of rocks that could have equilibrated with the thermal waters. Of course, conclusions derived from this approach have direct application only to the origin of $\mathrm{Pb}$ and $\mathrm{Sr}$ in the hydrothermal deposits.

For some years, the U.S. Geological Survey and independent scientists have studied the Yellowstone hydrothermal systems, and considerable information is available on the (stable) isotopic and chemical compositions of thermal waters in the area and the regional geology and geophysics. Quaternary volcanism at Yellowstone comprised three main cycles of activity which culminated about $1.9,1.2$, and $0.6 \mathrm{~m} . \mathrm{y}$. ago, respectively, with eruption of enormous rhyolite ash flows and collapse of the volcanic source area to form calderas (CHRISTIANSEN and BlaNK, 1972; written commun., 1976). Rhyolite flows erupted from ring fractures associated with the youngest caldera at least as recently as 70,000 years ago (EATON et al., 1975). The presently active thermal systems at Yellowstone probably date from this youngest magmatic insurgence. Geophysical evidence (EATON et al., 1975) strongly indicated the presence of a large magma body at relatively shallow depth beneath large parts of the Yellowstone Plateau, thus the source of heat in the park's hydrothermal systems is predominantly magmatic. Current hydrothermal activity is concentrated near ring-

*Current address: Department of Geology, Oregon State University, Corvallis, Oregon 97331 U.S.A. 
Table 1. Samples analyzed in this study

\begin{tabular}{|c|c|c|}
\hline Map. No. & Sample No. & Description \\
\hline 1 & Y10-6.7 & $\begin{array}{l}\text { Travertine core, drill hole Y10 (WHITE et al., 1975), } \\
\text { Mammoth Terrace, Mammoth Hot Springs }\end{array}$ \\
\hline 1 & YM-293 & Travertine, New Highland Terrace, Mammoth Hot Springs \\
\hline 1 & YM-382 & $\begin{array}{l}\text { Water collected at } 73^{\circ} \mathrm{C} \text {, New Highland Spring, Mammoth } \\
\text { Hot Springs }\end{array}$ \\
\hline 2 & YM-294 & Travertine Terrace Mountain, inactive springs \\
\hline 3 & W705-C2 & $\begin{array}{l}\text { Manganiferous travertine, East Black Warrior Lake, Lower } \\
\text { Geyser Basin }\end{array}$ \\
\hline 4 & YM-204 & $\begin{array}{l}\text { Manganiferous travertine, Hillside Spring, Upper Geyser } \\
\text { Basin }\end{array}$ \\
\hline 4 & W705-E2 & Siliceous sinter, Sapphire Geyser, Upper Geyser Basin \\
\hline - & 6YR-158 & Madison Limestone (Mississippian) (RUPPEL, 1972) \\
\hline - & 7YR-249 & $\begin{array}{l}\text { Composite sample of Mesozoic limestones of the Sawtooth, } \\
\text { Rierdon, Swift, Morrison and Kootenai Formations } \\
\text { (RUPPEL, 1972) }\end{array}$ \\
\hline
\end{tabular}



Fig. 1. Map of Yellowstone National Park (heavy dashed boundary) showing distribution of hot spring deposits (black areas) and sample localities (numbers, see Table 1 for description) with respect to structural features of Yellowstone caldera. The caldera rim is shown by solid line (where mappable) and dotted line (where inferred). Major ring-fracture zones are shown by light dashed line and areas of resurgent rhyolite domes are shown by stippled pattern. Map is simplified from one provided by R. L. CHRISTIANSEN (written com. 1975).

fracture zones and along a linear north-south trending fault zone (the Norris-Mammoth corridor). Most thermal springs with significant discharge rates lie within the caldera formed $0.6 \mathrm{~m}$.y. ago (Yellowstone caldera). A major exception to this generality is Mammoth Hot Springs, which occur at the north end of the Norris-Mammoth corridor, outside of the caldera proper. The Mammoth springs are situated on predominantly sedimentary strata of late Paleozoic and Mesozoic age (RuPPEL, 1972), whereas springs located within the caldera issue mainly from volcanic rocks or volcanistic sediments. In this study we analyzed hot-spring deposits from both within and outside the caldera rim to determine if any differences in isotopic composition exist between waters issuing from volcanic rocks and those that come from sedimentary rocks. We reasoned that magmatic $\mathrm{Pb}$ or Sr would be most easily detected in waters from springs located within the caldera because these waters are most likely to interact via deep convective circulation with the cooling magma body beneath the park. Descriptions of the analyzed samples are given in Table 1 and their locations are shown in Fig. 1.

\section{Chemical Compositions of Thermal Waters}

The wide diversity of hot spring types and water compositions found at Yellowstone $\mathrm{Na}$ tional Park has led many investigators to conclude that many discrete hydrothermal systems have operated. Recently, TruesDell and FouRNIER (1976) have suggested that these systems are separate only near the surface and that all can be related to a single large geothermal aquifer at depth which contains dilute brine at $340^{\circ}$ to $370^{\circ} \mathrm{C}$. According to their model, this deep thermal water cools by expansion and evaporation as it ascends into near-surface geyser and hot-spring systems where it undergoes differing degrees of dilution with cold meteoric water, reaction with rocks, and further steam loss to produce the various hot-spring waters. Regardless of which view is taken, the $\mathrm{Cl}^{-}$-rich 
Table 2. Chemical composition of the springs studied

\begin{tabular}{lccccccccc}
\hline & $\mathrm{T}\left({ }^{\circ} \mathrm{C}\right)$ & $\mathrm{pH}$ & $\mathrm{ppm} \mathrm{Si}$ & $\mathrm{ppm} \mathrm{Ca}$ & $\mathrm{ppm} \mathrm{Na}$ & $\mathrm{ppm} \mathrm{K}$ & $\mathrm{ppm} \mathrm{HCO}$ & $\mathrm{ppm} \mathrm{SO}_{4}^{=}$ & $\mathrm{ppm} \mathrm{Cl}^{-}$ \\
\hline Mammoth Hot Springs & $69-75$ & $6.3-6.9$ & $46-60$ & $209-338$ & $122-143$ & $42-69$ & $526-871$ & $477-578$ & $161-170$ \\
Black Warrior Lake & 93 & 7.3 & 199 & 14 & 89 & 13 & 150 & 26 & 52 \\
$\quad$ (vent) & & & & & & & & & \\
Hillside Springs & 86 & $6.5-7.4$ & $175-190$ & 8.4 & $124-145$ & $6.9-8.3$ & $246-252$ & $12-17$ & $66-72$ \\
Sapphire Geyser & $90-95$ & $8.1-9.2$ & $320-355$ & $0.3-1.6$ & $412-445$ & $16-20$ & $332-406$ & $14-55$ & $296-308$ \\
\hline
\end{tabular}

Note: All data in this table are taken from RowE et al. (1973).

acid waters of Norris Geyser Basin are believed to be most representative of deep-seated thermal waters, although even these waters probably are diluted by meteoric water. Chemical compositions of several other kinds of thermal water in the park are briefly summarized below.

Significant differences in chemical composition are found between the thermal waters from Mammoth Hot Springs and those from within the caldera (Rowe et al., 1973). Partial chemical analyses of waters from the springs studied in this paper are given in Table 2. Aquifer temperatures inferred from dissolved silica content and direct drilling range from about $170^{\circ}$ to $250^{\circ} \mathrm{C}$ for intracaldera springs having large discharge rates, as compared to about $72^{\circ} \mathrm{C}$ for Mammoth (FourNIER and Rowe, 1966; FourNIER and Truesdell, 1971; and White et al., 1975). The latter figure agrees closely with orifice temperatures measured at Mammoth (FrIEDMAN, 1970; Rowe et al., 1973). $\mathrm{Na} / \mathrm{K}$ ratios in Mammoth spring waters are significantly lower than those in intracaldera thermal waters. This difference may result from equilibration of thermal waters in the two areas with different mineral buffers in their respective aquifers. Other important differences between waters at Mammoth and those in the caldera, such as comparatively high $\mathrm{SO}_{4}^{-}, \mathrm{Ca}$, and $\mathrm{HCO}_{3}^{-}$in the Mammoth water, may result from equilibration of the Mammoth water with marine evaporites and limestones. In addition, mixture of cold meteoric water with thermal water may have contributed to increased solubility of calcite at Mammoth (TRUESDELl and Fournier, 1976). Waters of Black Warrior Lake (vent) differ from most intracaldera thermal waters in having lower $\mathrm{Na} / \mathrm{K}$ and $\mathrm{Cl}^{-}$. Because the Black Warrior springs have extremely large discharge rates, FouRNIER and TRuesdell (1971) suggested that the low present-day $\mathrm{Na} / \mathrm{K}$ ratios have resulted from previous leaching of Na-bearing minerals from the aquifer. Rowe et al. (1973) consider Black Warrior water typical of hot-spring waters that have been diluted by meteoric water at shallow depth. Hillside Spring water closely resembles that at Black Warrior Lake. Sapphire Geyser water is typical of dilute thermal water that is high in $\mathrm{HCO}_{3}^{-}$as the result of extensive nearsurface water- $\mathrm{CO}_{2}$-rock reaction (TRUESDELL and FOURNIER, 1976).

\section{STABle Isotope STUdies}

CRAIG (1963) has shown that $\mathrm{CO}_{3}=$-rich thermal waters at Mammoth Hot Springs have $\delta \mathrm{D}$ and $\delta^{18} \mathrm{O}$ values close to those of local streams and precipitation, and that deviations from these values (most pronounced in acid, boiling pools) follow an evaporation trend. Thus, acid, $\mathrm{SO}_{4^{-}}$ rich waters, such as those in Upper Geyser Basin, are probably derived by evaporation of mixed groundwater and deep-seated water, with oxidation of $\mathrm{H}_{2} \mathrm{~S}$ to $\mathrm{H}_{2} \mathrm{SO}_{4}$. CRAIG concluded mainly from studies of other geothermal systems that most $(>95 \%)$ of the discharge volume of such thermal waters is of direct meteoric origin (CRAIG et al., 1956). MAZOR and WASSERBURG (1965) found a scarcity of ${ }^{40} \mathrm{Ar}$ and other rare gases in Yellowstone Park thermal waters, also providing evidence against the presence of a significant amount of magmatic gas component. Craig (1963) also noted that $\delta^{13} \mathrm{C}$ values (in $\mathrm{HCO}_{3}^{-}, \mathrm{CaCO}_{3}$, and $\mathrm{CO}_{2}$ ) in Yellowstone Park hot springs were closely similar to those in marine limestones, and he suggested that $\mathrm{C}$ in the hydrothermal systems is principally derived from limestone or exchanged with $\mathrm{C}$ in limestone to such an extent that another source cannot be recognized.

It Table 3, we present new $\mathrm{C}$ and $\mathrm{O}$ isotopic analyses of two travertines from the Mammoth area and one from Hillside Springs. The Mammoth area travertines have $\delta^{13} \mathrm{C}$ and $\delta^{18} \mathrm{O}$ values in the range of those reported by FRIEDMAN (1970), and the Hillside travertine is significantly lighter in $\delta^{13} \mathrm{C}$, but all values are near the range for marine carbonates. The temperature dependence of $\mathrm{C}$ and $\mathrm{O}$ isotopic fractionations between thermal waters and pre- 
Table 3. Carbon and oxygen isotopic compositions



${ }^{a}$ Note: all carbon and oxygen analyses are referred to the PDB and SMOW standards, respectively.

${ }^{b}$ Analyst: J. WHELAN.

${ }^{c}$ Value taken for travertine deposited at $73^{\circ} \mathrm{C}$ at spring orifice, Mammoth Hot Springs; coexisting water had $\delta^{18} \mathrm{O}=+18.11 \%$.

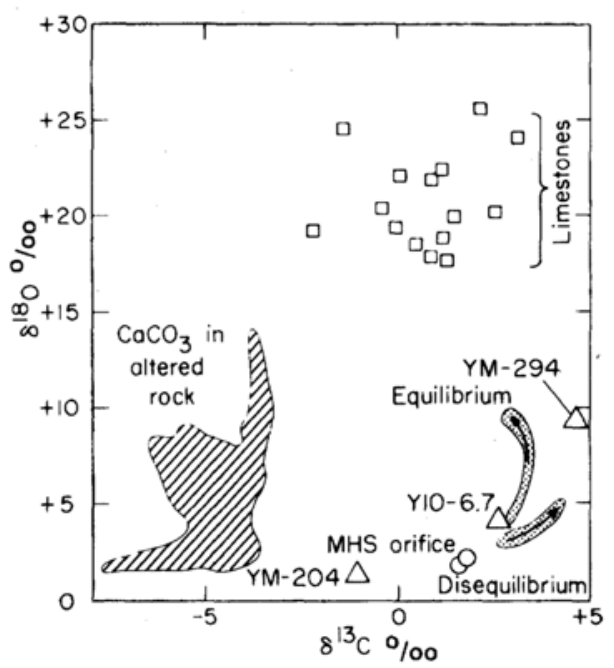

Fig. 2. Relations between $\delta^{13} \mathrm{C}$ and $\delta^{18} \mathrm{O}$ in travertines from Yellowstone National Park. Analyses from this paper are shown as triangles; open circles represent orifice travertine from Mammoth Hot Springs (MHS); stippled equilibrium and disequilibrium trends are shown for two springs at MHS (FRIEDMAN, 1970); open squares represent Phanerozoic limestones from the Gardiner area (FRIEDMAN, 1970). Carbonates in altered rocks from Wairakei, New Zealand (CLAYTON and STEINER, 1975) and Salton Sea, California (CLAYTON et al., 1968), hydrothermal systems are shown for reference.

cipitated travertines is clearly demonstrated in FrIEDMAN's (1970) study of Mammoth Hot Springs (see Fig. 2). The results of that study suggest that our samples of Mammoth travertine precipitated at temperatures substantially below that of the present-day orifice (about $73^{\circ} \mathrm{C}$ ). In fact, the Terrace Mountain travertine probably formed slowly in a cold proglacial lake.

FrIEDMAN (1970) showed that Mammoth waters presently discharge with $\delta^{18} \mathrm{O}$ values of about -18.1 permil at their orifice temperature. If it is assumed that Hillside Spring travertine precipitates at a similar temperature $\left(\mathrm{T}=86^{\circ} \mathrm{C}\right.$ for issuing water, Table 2), $\delta^{18} \mathrm{O}$ in the equilibrium water would be about -18.5 permil. In neither of these hot springs does the thermal water reflect equilibration with marine carbonates, with fresh volcanic rock like the local rhyolites (Friedman et al., 1974; Friedman, pers. com. 1975) or altered rocks like those in the Salton Sea (CLAYTON et al., 1958) or Wairakei (CLAYTON and STEINER, 1975) hydrothermal systems (see Fig. 2). Oxygen in the Yellowstone thermal waters probably is buffered by oxygen in the large volumes of meteoric water circulating in that hydrothermal system, and exchange with reservoir rocks probably is comparatively insignificant.

SCHOEN and R Ye (1970) found a small range of $\delta^{34} \mathrm{~S}$ values in $\mathrm{H}_{2} \mathrm{~S}(+0.7$ to +2.6 permil) and native $S(-1.7$ to +1.4 permil, relative to coexisting $\mathrm{H}_{2} \mathrm{~S}$ ) for springs within the caldera or close to the ring fracture zone (including Norris Geyser Basin). They concluded that most of the $\mathrm{H}_{2} \mathrm{~S}$ rising to the surface in these areas comes either from a body of degassing magma or from igneous rocks containing unfractionated 
sulfur. In contrast, respective $\delta^{34} \mathrm{~S}$ values for $\mathrm{H}_{2} \mathrm{~S}$ and $\mathrm{S}$ at Mammoth are -3.0 and -8.4 permil. The depletions in ${ }^{34} \mathrm{~S}$ indicated by these values were tentatively attributed to the presence of a sedimentary component $\left(\mathrm{H}_{2} \mathrm{~S}\right.$ baked out of underlying sediments) and bacterial oxidation of $\mathrm{H}_{2} \mathrm{~S}$ to form light $\mathrm{S}$. Water at Mammoth Hot Springs contained very heavy $\mathrm{SO}_{4}^{=}\left(\delta^{34} \mathrm{~S}=+20.5\right.$ permil $)$, compared with $\mathrm{SO}_{4}^{=}$ from other areas $\left(\delta^{34} \mathrm{~S}\right.$ ranged from +1.8 to 3.3 permil), suggesting that sulfur in the Mammoth water was derived largely from marine evaporites.

\section{Lead and Strontium Isotopic Tracer Studies}

Radiogenic isotopes are potentially useful in elucidating the origin of thermal waters if representative end-member components can be analyzed, and if variations in isotopic composition in these materials are sufficiently large compared with analytical uncertainties. $\mathrm{Pb}$ and $\mathrm{Sr}$ isotopic ratios measured for hot spring deposits can confidently be considered representative of those ratios in the associated thermal waters because, unlike constitutents or light stable isotopes, the heavy nuclides are not significantly fractionated during chemical reactions. Variations in $\mathrm{Pb}$ and $\mathrm{Sr}$ isotopic composition in hot-spring deposits may result from mixing in variable proportions of $\mathrm{Pb}$ and $\mathrm{Sr}$ derived from two or more reservoirs. At Yellowstone National Park we are concerned with two major reservoirs: rhyolitic lavas and tuffs (these are considered representative of a rhyolitic magma body at depth), and sedimentary rocks exposed outside of Yellowstone caldera. Because the $\mathrm{Pb}$ and $\mathrm{Sr}$ contents of meteoric waters are generally quite low (WEDEPOHL, 1974; TUREKIAN, in press), isotopic compositions of these elements probably will be dominated by $\mathrm{Pb}$ and $\mathrm{Sr}$ in the rocks in contact with such waters.

We have analyzed numerous samples of rhyolite lava and tuff, a sample of Mississippian Madison Limestone, and a composite sample of Mesozoic sedimentary rocks from the area near Mammoth Hot Springs. Our sampling of rhyolitic rocks covers the entire chronological and spatial distribution of rhyolites at Yellowstone, and is therefore considered representative of the range in isotopic composition of these rocks. Such variations as occur are relatively small in magnitude and are briefly described below. Our sampling of the sedimentary column is admittedly minimal, but because the analyses are similar to those of other limestones of similar age (see below), we consider them at least indicative.

$\mathrm{Pb}$ isotopic analyses were carried out using either the $\mathrm{PbS}$ method (DoE et al., 1967) or the silica gel- $\mathrm{H}_{3} \mathrm{PO}_{4}$ method (CAMERON et al: 1969), and a 12-inch-radius NBS mass spectrometer. Samples were dissolved in dilute $\mathrm{HCl}$ (carbonates) or in $\mathrm{HF}^{-} \mathrm{HClO}_{4}$ (silicates), and $\mathrm{Pb}$ was extracted using dithizone (only for samples analyzed by the $\mathrm{PbS}$ method), anodic electrodeposition or $\mathrm{HBr}$ cation exchange. Blanks were about $50 \mathrm{ng} / \mathrm{g}$ sample during early stages of this work and were reduced to about $10 \mathrm{ng} / \mathrm{g}$ sample during later stages when samples with very low $\mathrm{Pb}$ contents were processed. All isotopic ratios were corrected for mass fractionation in the spectrometer via intercomparison with the NBS common lead standard and BCR-1 reference sample. Isotopic ratios reported relative to ${ }^{204} \mathrm{~Pb}$ are believed accurate to $\pm 0.15 \%$, or better in the case of the silica gel analyses. $\mathrm{Sr}$ isotopic analyses were carried out on a 6inch-radius mass spectrometer with digital recording of data. Normalized ${ }^{87} \mathrm{Sr} /{ }^{86} \mathrm{Sr}$ ratios are adjusted to a value of 0.7080 for the $\mathrm{E} \& \mathrm{~A}$ $\mathrm{SrCO}_{3}$ reference standard, and are believed accurate to \pm 0.0003 . All concentration data for $\mathrm{Pb}, \mathrm{U}, \mathrm{Th}, \mathrm{Rb}$, and $\mathrm{Sr}$ were determined by isotope dilution and are believed accurate to $\pm 5 \%$ or better.

Strontium isotopic ratios and $\mathrm{Rb}$ and $\mathrm{Sr}$ contents of travertines, thermal water from Mammoth, sedimentary rocks, and several rhyolites are given in Table 4. Three travertines from the Mammoth area have essentially the same ${ }^{87} \mathrm{Sr} /{ }^{86} \mathrm{Sr}$ ratio $(0.710)$ as the water collected there, whereas travertine from Black Warrior Lake, within the caldera, has a slightly higher value. These variations are not large and may not be geologically significant. The two limestones differ greatly: the Madison Limestone has about the same ${ }^{87} \mathrm{Sr} /{ }^{86} \mathrm{Sr}$ ratio as the travertines, and the leach (carbonate) fraction of the Mesozoic limestone has a much lower value. The residue (clastic) fraction of Mesozoic limestone contains rather radiogenic $\mathrm{Sr}$, which is consistent with a detrital provenance having an apparent middle to late Paleozoic age. Present-day ${ }^{87} \mathrm{Sr} /{ }^{86} \mathrm{Sr}$ ratios in Yellowstone Park rhyolites are also fairly radiogenic, increasing with increasing $\mathrm{Rb} / \mathrm{Sr}$. Initial ${ }^{87} \mathrm{Sr} /{ }^{86} \mathrm{Sr}$ ratios corrected. for in situ decay of ${ }^{87} \mathrm{Rb}$ since the rocks crystallized, or such ratios measured in 
Table 4. Strontium isotopic compositions and contents of rubidium and strontium in selected travertines, sediments and volcanic rocks

\begin{tabular}{|c|c|c|c|c|c|c|}
\hline \multicolumn{3}{|c|}{ Sample } & $\mathrm{ppm} \mathrm{Rb}$ & ppm Sr & ${ }^{87} \mathrm{Sr}$ & $\mathrm{Rb} / \mathrm{Sr}$ \\
\hline & \multicolumn{6}{|l|}{ Travertines } \\
\hline 1 & Y10-617 & leach & 0.13 & 1610. & 0.7106 & 0.00008 \\
\hline 2 & YM-294 & leach & - & - & 0.7103 & \\
\hline 3 & YM-293 & leach & - & - & 0.7103 & \\
\hline \multirow[t]{2}{*}{4} & W-705-C2 & leach & - & - & 0.7111 & \\
\hline & \multicolumn{6}{|c|}{ Water, Mammoth Hot Springs } \\
\hline \multirow[t]{2}{*}{4} & YM-382 & & 0.30 & 1.7 & 0.7103 & 0.177 \\
\hline & \multicolumn{6}{|c|}{ Sedimentary carbonates } \\
\hline 6 & 6YR-158 & leach & 0.50 & 40.7 & 0.7109 & 0.0123 \\
\hline 7 & 7YR-249 & leach & 1.73 & 356. & 0.7074 & 0.00486 \\
\hline 8 & 7YR-249 & residue & 34.9 & 59. & 0.7186 & 0.592 \\
\hline \multirow[t]{2}{*}{9} & 7YR-249 & $\begin{array}{l}\text { whole rock } \\
\text { (calc) }\end{array}$ & 11. & 273. & 0.7081 & 0.0403 \\
\hline & \multicolumn{6}{|l|}{ Rhyolites } \\
\hline 10 & 6YC-138 & & 221. & 18. & 0.7121 & 12.3 \\
\hline 11 & YR-3 & & 289. & 2.4 & 0.7276 & 120. \\
\hline 12 & YR-5 & & 181. & 20.5 & 0.7130 & 8.82 \\
\hline 13 & YR-6 & & 165. & 36.9 & 0.7115 & 4.47 \\
\hline
\end{tabular}

Analysts: W. T. HENDERSON and R. A. HILDRETH (Nos. 1-10), W. I. MANTON (Nos. 11-13, pers. com. 1970).

feldspar separates having low $\mathrm{Rb} / \mathrm{Sr}$, (DOE, Christiansen, Hedge and LeEman, unpublished data), are less radiogenic and much more uniform, averaging about 0.710 . These values might be more representative of the isotopic composition of $\mathrm{Sr}$ in the magma chamber beneath the park.

Although material balance models can be made to account for the isotopic composition of $\mathrm{Sr}$ in the park's thermal waters, such calculations give no unique result because the analyzed reservoir rocks are so similar in ${ }^{87} \mathrm{Sr} /{ }^{86} \mathrm{Sr}$ to the travertines. $\mathrm{Sr}$ in the thermal waters could be derived from (1) a cooling rhyolitic magma body, (2) limestone like the Madison, or (3) a combination of nonradiogenic Mesozoic limestone and rhyolitic lavas and tuffs. Although the travertines have high $\mathrm{Sr}$ contents, the waters from which they precipitate contain little $\mathrm{Sr}$ (about $2 \mathrm{ppm}$ ). Thus any or all of the potential $\mathrm{Sr}$ reservoir rocks we analyzed may be important in the overall $\mathrm{Sr}$ budget, with the exception of the low-Sr rhyolites. Basalts in Yellowstone Park typically contain about $300 \mathrm{ppm} \mathrm{Sr}$, and have ${ }^{87} \mathrm{Sr} /{ }^{86} \mathrm{Sr}$ ratios close to 0.706 . However, basaltic rocks are present only in small volumes and are not considered as significant reservoir rocks.

Lead isotopic ratios and $\mathrm{Pb}, \mathrm{U}$, and $\mathrm{Th}$ contents are given in Table 5 for rhyolites (only our silica gel analyses are given), and Table 6 for hot spring deposits and sediments at Yellowstone. We do not intend to discuss here the petrogenetic significance of these data, but it is of interest that Yellowstone Park basalts (Doe, Christiansen, Hedge and Leeman, unpublished data) have lead isotopic compositions in the same range as the rhyolites. Leads in Yellowstone Park rhyolites can be distinguished into three main compositional groups: (1) the extensive ash flows and the voluminous rhyolite flows which preceded them, which have ${ }^{206} \mathrm{~Pb} /$ ${ }^{204} \mathrm{~Pb}$ ratios between 16.88 and 17.30 ; (2) intracaldera flows with ${ }^{206} \mathrm{~Pb} /{ }^{204} \mathrm{~Pb}$ ratios ranging from 17.55 to 17.63 ; and (3) flows outside the caldera with values less than 16.9. Both (2) and (3) apply to rhyolites less than $0.6 \mathrm{~m}$.y. old. Possibly the post-caldera rhyolites which erupted outside the ring fracture zone (group 3) are more representative of lower crustal lead, whereas the late-stage intracaldera rhyolites (group 2) reacted with earlier emplaced granitic bodies contaminated with upper crust and through which the intracaldera rhyolites ascended. We also reanalyzed by the silica gel method two andesites from the Absaroka Volcanic Supergroup. Peterman et al. (1970) presented $\mathrm{PbS}$ analyses of these and other volcanic rocks. The $\mathrm{Pb}$ isotopic composition of Absaroka rhyolites and shoshonites overlaps 
Table 5. Lead contents and isotopic compositions of selected rhyolites

\begin{tabular}{|c|c|c|c|c|c|c|c|}
\hline & Sample & Material & ppm $\mathrm{Pb}$ & $\frac{{ }^{206} \mathrm{~Pb}}{{ }^{204} \mathrm{~Pb}}$ & $\frac{{ }^{207} \mathrm{~Pb}}{{ }^{204} \mathrm{~Pb}}$ & $\frac{{ }^{208} \mathrm{~Pb}}{{ }^{204} \mathrm{~Pb}}$ & Geologic Unit \\
\hline 1 & YG-72-5 & Glass & 33.5 & 17.549 & 15.568 & 38.329 & West Yellowstone flow \\
\hline $2 \mathrm{a}$ & $720-76$ & Glass & 32.8 & 17.631 & 15.595 & 38.335 & Nez Perce flow \\
\hline $2 b$ & & Sanidine & 27.6 & 17.622 & 15.590 & 38.323 & \\
\hline 3 & OCB66-13 & Sanidine & - & 17.553 & 15.546 & 38.229 & Dry Creek flow \\
\hline 4 & 6YR-138 & Glass & 31.7 & 16.599 & 15.425 & 38.415 & Cougar Creek flow \\
\hline 5 & 6YR-137 & Glass & 36.5 & 17.137 & 15.538 & 38.289 & Obsidian Cliff flow \\
\hline $6 a$ & 2YR-118 & Sanidine & - & 16.871 & 15.470 & 38.003 & Rhyolite from Snake River Butte \\
\hline $6 \mathrm{~b}$ & & & & 16.892 & 15.492 & 38.049 & \\
\hline 7 & $690-20$ & Sanidine & - & 17.245 & 15.553 & 38.334 & Rhyolite from Osborne Butte \\
\hline 8 & OCB-563 & Sanidine & - & 17.291 & 15.573 & 38.447 & Lewis Canyon Rhyolite \\
\hline 9 & OCB-601 & Sanidine & - & 17.253 & 15.559 & 38.279 & Mount Jackson Rhyolite \\
\hline 10 & YG70-4 & Sanidine & - & 17.269 & 15.550 & 38.434 & Upper Falls, Uncle Tom Parkin \\
\hline 11 & $6 \mathrm{YC}-146$ & Glass & 31.3 & 17.299 & 15.544 & 38.415 & Lava Creed Tuff, mbr. B \\
\hline 12 & OCB66-01 & Sanidine & - & 16.995 & 15.491 & 38.057 & Huckleberry Ridge Tuff, mbr. 8 \\
\hline 13 & P-496 & Whole rock & 14.7 & 16.260 & 15.350 & 36.678 & $\begin{array}{l}\text { Andesite from the Absaroka Volcanic } \\
\text { Supergroup, Washburn center }\end{array}$ \\
\hline 14 & 7PD-1 & Whole rock & 11.9 & 16.521 & 15.389 & 36.888 & $\begin{array}{l}\text { Andesite from the Absaroka Volcanic } \\
\text { Supergroup, Sunlight center }\end{array}$ \\
\hline
\end{tabular}

Note: all analyses in this table are by the silica gel technique and are corrected for mass fractionation during the analysis.

Analysts: W. P. LEEMAN (Nos. 1, 2a, 2b, 6b, 8, 9, 13, 14) and M. H. DELEVAUX (Nos. 3, 4, 5, 6a, 7, 10, 11, 12).

Table 6. Lead, uranium and thorium contents and lead isotopic compositions of selected travertines and sedimentary carbonates

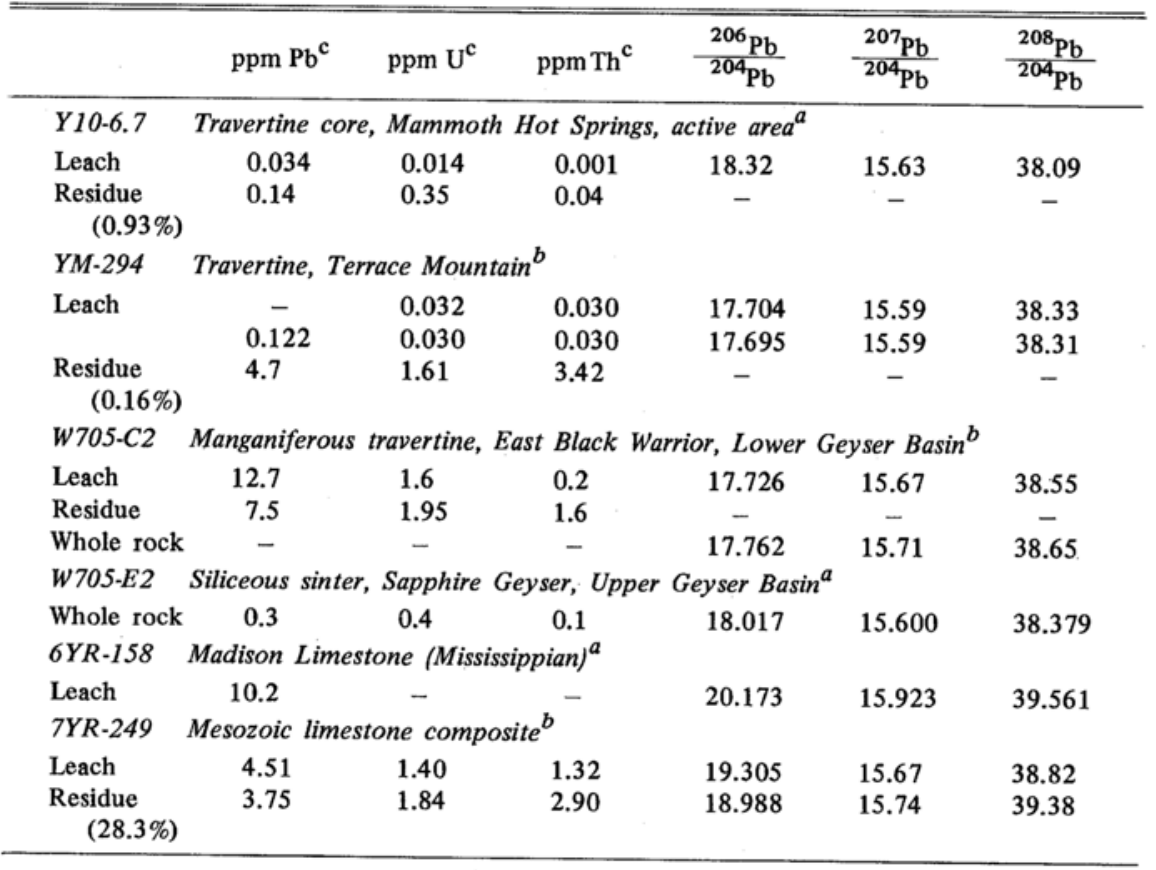

${ }^{a}$ Isotopic composition analyzed by W. P. LEEMAN, using silica gel.

${ }^{b}$ Isotopic composition analyzed by $\mathrm{B}$. $\mathrm{R}$. DOE, using $\mathrm{PbS}-\mathrm{NH}_{4} \mathrm{OH}$.

${ }^{c}$ All concentration analyses are by DOE, except for sample $6 Y R-158$ (LEEMAN). 
that of Yellowstone Park, but the Absaroka andesites contain less radiogenic $\mathrm{Pb}$ that may be representative of lower crustal $\mathrm{Pb}$.

Lead in the Madison Limestone and in the Mesozoic limestone composite is quite radiogenic, with ${ }^{206} \mathrm{~Pb} /{ }^{204} \mathrm{~Pb}$ ratios greater than 19.0 . This radiogenic character is typical of leads from marine limestones (DoE, 1970), and may reflect deposition in the ocean basins of radiogenic lead derived from weathering of old continental crustal material having high $\mathrm{U} / \mathrm{Pb}$ ratios. The carbonate fraction of the Mesozoic composite contains more radiogenic lead than the clastic fraction. Although our sampling of the sedimentary section is minimal, the similarity of our samples to other marine limestones (Fig. 3) suggests there is a distinct isotopic difference between leads in Yellowstone's sedimentary rocks and leads in the rhyolites.

Isotopic compositions of lead in the hotspring deposits vary slightly, but all have ${ }^{206} \mathrm{~Pb} /$ ${ }^{204} \mathrm{~Pb}$ ratios between those of the rhyolites and the sediments, and these ratios plot close to a line between the two fields representing those rock types in a ${ }^{206} \mathrm{~Pb} /{ }^{204} \mathrm{~Pb}{ }^{207} \mathrm{~Pb} /{ }^{204} \mathrm{~Pb}$ plot (Fig. 3). Such linear arrays occasionally have been interpreted as secondary isochrons, but in this case the array almost certainly represents mixing of volcanic and sedimentary lead in the thermal waters. There is no consistent correlation between isotopic composition and locality of the hot springs. Leads in travertine from Mammoth Hot Springs and Terrace Mtn., both located outside the caldera, have the highest and lowest ${ }^{206} \mathrm{~Pb} /{ }^{204} \mathrm{~Pb}$ ratios, respectively,
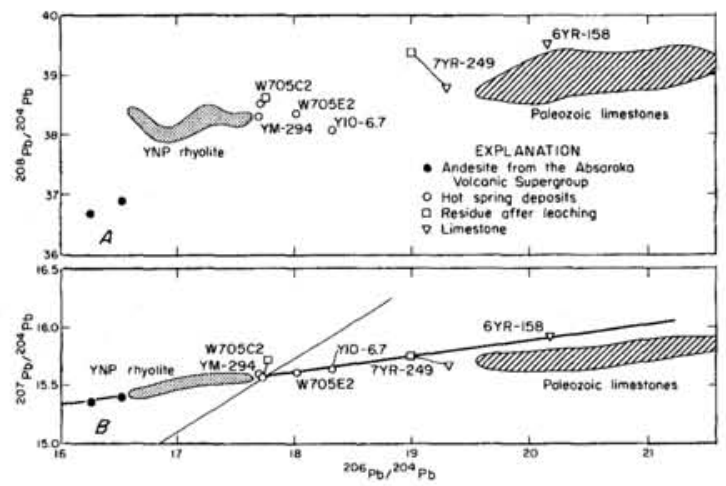

Fig. 3. Lead isotope systematics for volcanic rocks, hot spring deposits, and limestones from Yellowstone $\mathrm{Na}$ tional Park. Analyses of Paleozoic limestones from Colorado and Nevada are shown for comparison (DOE, 1976). whereas lead in siliceous sinter from Sapphire Geyser has a ratio between these two values and lead in travertine from Black Warrior Lake has a composition close to that at Terrace Mtn. Systematics in the ${ }^{208} \mathrm{~Pb} /{ }^{204} \mathrm{~Pb}-{ }^{206} \mathrm{~Pb} /{ }^{204} \mathrm{~Pb}$ diagram are not as straight forward, mainly because ${ }^{208} \mathrm{~Pb} /{ }^{204} \mathrm{~Pb}$ ratios are more variable in the reservoir rocks, but the diagram is consistent with the mixing hypothesis. Without information on the partitioning of $\mathrm{Pb}$ between travertine or sinter and thermal waters, or more detailed study of the sediments, we cannot present a quantitative assessment of the mixing relations. Nevertheless, it appears that lead in hot springs, even within the caldera, contains a significant amount of component derived from the sedimentary section. None of the hot spring deposits seem to contain lead solely of volcanic origin.

\section{CONCLUSIONS}

Chemical and isotopic studies of hydrothermal systems in Yellowstone National Park indicate that the minor element composition of thermal waters is derived from complex interaction with two main reservoirs: (1) the volcanic rocks and/or the subjacent magma chamber, and (2) the sedimentary (and minor igneous) rocks underlying the park and in the drainage areas for meteoric waters at the park. The sedimentary reservoir is expectedly diverse in composition and has not yet been adequately sampled. On the other hand, the Yellowstone volcanic-plutonic reservoir can be characterized reasonably well on the basis of present sampling. With these limitations in mind, the thermal waters appear to contain significant amounts of components of both volcanic and sedimentary $\mathrm{Pb}$ and $\mathrm{Sr}$. C and $\mathrm{S}$ (at Mammoth Hot Springs) are derived mainly from the sedimentary reservoir, and $\mathrm{H}$ and $\mathrm{O}$ are believed to be predominantly meteoric. Thus the amounts of these elements contained in the various hot springs are controlled by the dominant reservoirs for each element. It should be noted that the volcanic $\mathrm{Pb}$ (and $\mathrm{Sr}$ ) detected in Yellowstone Park hot springs may be derived entirely by leaching of volcanic rocks and does not necessarily indicate a direct magmatic water component. The presence of significant amounts of sedimentary $\mathrm{Pb}$ in all the hot springs studied within Yellowstone caldera indicates that sedimentary rocks are present in the aquifers of these springs. Involvement of sediments also seems likely on the basis of field observations, because travertine is found within the caldera, and formation of travertine 
through leaching of silicate volcanic rocks is unlikely. The presence of the travertine and the isotopic evidence could be taken to indicate the presence of sedimentary rocks somewhere within the caldera. Although the presence of such rocks at depth cannot be precluded, the mapping of R. L. CHRISTIANSEN (written commun., 1976) indicates that they are at least scarce at the surface of the caldera. If sedimentary rocks are indeed absent within the caldera, the conclusion would be that much of the water circulating through the Yellowstone hydrothermal systems is derived from recharge areas well outside the caldera ring-fracture zone. This conclusion would also require the travertine forming components to be introduced to the area. Therefore, no unique conclusion can be reached as to the location of the sediments, but, because the major rainfall in the area occurs within the caldera, the favored interpretation is that sedimentary rocks must exist at depth within the caldera limits.

This study illustrates the utility of tracer studies of hydrothermal systems, particularly when several isotopic systems are employed. Under favorable conditions, information can be obtained regarding the nature of reservoir rocks, elemental budgets, and hydrologic characteristics of such hydrothermal systems.

Acknowledgments-The authors are grateful to L. J. P. MUFFLER for guiding the collection of samples or for providing the samples studied, and to D. E. WHITE, L. J. P. MUfFler, A. L. TRUESDELl, and I. Friedman for helpful discussions concerning this study. W. P. LEEMAN acknowledges the National Research Council for support with a postdoctoral fellowship.

\section{REFERENCES}

CAMERon, A. E., SMith, D. H. and Walker, R. L. (1969) Mass spectrometry of nanogram-size samples of lead. Anal. Chem. 41, 525-526.

Christiansen, R. L. and BLANK, H. R., JR. (1972) Volcanic stratigraphy of the Quaternary rhyolite plateau in Yellowstone National Park. U.S. Geol. Survey Prof. Paper 729-B, B1-B18.

Clayton, R. N., Muffler, L. J. P. and White, D. E. (1968) Oxygen isotope study of calcite and silicates of the River Ranch No.1 well, Salton Sea geothermal field, Califernia. Am. J. Sci. 266, 968-979.

Clayton, R. N. and Steiner, A. (1975) Oxygen isotope studies of the geothermal systems at Wairakei, New Zealand. Goechim. Cosmochim. Acta 39, 11791186.
CRAIG, H. (1963) The isotopic geochemistry of water and carbon in geothermal areas, in Nuclear geology on geothermal areas (Spoleto, 1963), ed. E. TONGIORGI, 17-53, Consiglio nazionale delle richerche, Pisa.

Craig, H., BoAto, G. and White, D. E. (1956) Isotopic geochemistry of thermal waters, in Nuclear processes in geologic settings, Natl. Research Council Nuclear Sc. Ser. Rept. 19, 29-38.

DEINES, P. and GoLD, D. P. (1973) The isotopic composition of carbonatite and kimberlite carbonates and their bearing on the isotopic composition of deep-seated carbon. Geochim. Cosmochim. Acta 37, 1709-1733.

DoE, B. R. (1970) Lead isotopes, in Minerals, rocks, and inorganic materials, Berlin-Heidelberg-New York, Springer-Verlag, 3, 137.

DOE, B. R. (1976) Lead isotope data bank: 2624 samples and analyses cited. U.S. Geol. Survey Openfile Report 76-201, $104 \mathrm{p}$.

DOE, B. R., TATSumoto, M., DelevauX, M. H. and Peterman, Z. E. (1967) Isotope dilution determinations of five elements in G-2 (granite), with a discussion of the analysis of lead. U.S. Geol. Survey Prof. Paper 575-B, B170-B177.

Eaton, G. P., Christiansen, R. L., IYer, H. M., PITT, A. M., MABEY, D. R., B LANK, H. R., ZIETZ, JR. and GetTingS, M. E. (1975) Magma beneath Yellowstone Nagional Park. Science 188, 787-796.

ELLIS, A. J. (1971) Qualitative interpretation of chemical characteristics of hydrothermal systems, in United Nations symposium on the development and utilization of geothermal resources (Pisa, 1970). Geothermics Spec. Issue 2, 2, 516-528.

FOURNIER, R. O. and RowE, J. J. (1966) Estimation of underground temperatures from the silica content of water from hot springs and wet- steam wells. $\mathrm{Am}$. J. Sci. 264, 685.

Fournier, R. O. and TRuesdell, A. H. (1971) Chemical indicators of subsurface temperature applied to hot spring waters of Yelloswtone National Park, Wyoming, U.S.A., in United Nations symposium on the development and utilization of geothermal resources (Pisa, 1970). Geothermics Spec. Issue 2, 2, 529-535.

FriedMan, I. (1970) Some investigations of the deposits of travertine from hot springs; I, The isotope chemistry of a travertine-depositing spring. Geochim. Cosmochim. Acta 34, 1303-1315.

Friedman, I., LIPMAN, P. W., ObRadovich, J. D., Gleason, J. D. and Christiansen, R. L. (1974) Meteoric water in magmas. Science 184, 10691072.

FUEX, A. N. and BAKER, D. R. (1973) Stable carbon isotopes in selected granitic, mafic and ultramafic 
igneous rocks. Geochim. Cosmochim. Acta 37, TUREKIAN, K. K. (in press) Solubilities of compounds 2509-2521.

MAHON, W. A. J. (1971) Chemistry in the exploration and exploitation of hydrothermal systems, in United Nations symposium on the development and utilization of geothermal resources (Pisa, 1970). Geothermics Spec. Issue 2, 2, 1310-1322.

MAZOR, E. and WASSERburG, G. J. (1965) Helium, neon, argon, krypton, and xenon in gas emanations from Yellowstone and Lassen Volcanic National Parks. Geochim. Cosmochim. Acta 29, 443-454.

Peterman, Z. E., Doe, B. R. and ProstKa, H. J. (1970) Lead and strontium isotopes in rocks of the Absaroka Volcanic field, Wyoming. Contrib. Mineral. Petrol. 27, 121-130.

ROWE, J. J., FOURNIER, R. O. and MOREY, G. W. (1973) Chemical analysis of thermal waters in Yellowstone National Park, Wyoming, 1960-1965. U.S. Geol. Survey Bull. 1303.

RUPPEL, E. T. (1972) Geology of Pre-Tertiary rocks in the northern part of Yellowstone National Park, Wyoming. U.S. Geol. Surv. Prof. Paper 729-A.

SCHOEN, R. and RYE, R. O. (1970) Sulfur isotope distribution in solfataras, Yellowstone National Park. Science 170, 1082-1084.

TAYLOR, H. P. JR. (1968) The oxygen isotope geochemistry of igneous rocks. Contrib. Mineral. Petrol. 19, 1-71.

Truesdell, A. H. and Fournier, R. O. (1976) Conditions on the deeper parts of the hot spring systems of Yellowstone National Park, Wyoming. U.S. Geol. Surv. Open-file Report, 76-428. which control the concentrations of strontium in natural waters; adsorption processes; valence states in natural environments, Chap. 38-H Handbook of geochemistry, ed. K. H. WEDEPOHL, Springer-Verlag.

U.S. Geological Survey (1972) Geologic map of Yellowstone National Park. U.S. Geological Survey Misc. Geol. Inv. Map 1-711.

WEDEPOHL, K. H. (1974) Chap. 82-H. Solubilities of compounds which control concentrations of lead in natural waters; valence states in natural environments; adsorption processes, Chap. 82-H Handbook of geochemistry, II-4, ed. K. H. WEDEPOHL, 82-H-1 to 82-H-4, Springer Verlag.

WHITE, D. E. (1969) Thermal and mineral waters of the United States: Brief review of possible origins. 23rd Intl. Geol. Congr., Section 10, 269-286.

WHITE, D. E. (1971) Geochemistry applied to the discovery, evaluation, and exploitation of geothermal energy resources, in United Nations symposium on the development and utilization of geothermal resources (Pisa, 1970). Geothermics Spec. Issue 2, $1,58-80$.

White, D. E., Fournier, R. O., Muffler, L. J.P. and TRuesdell, A. H. (1975) Physical results of research drilling in thermal areas of Yellowstone National Park, Wyoming. U.S. Geol. Survey Prof. Paper 892. 